\title{
Nutrient Content Evaluation of Dried Poultry Waste Urea Molasses Block (DPW-UMB) on In-vitro Analysis
}

\author{
D. N. Adli* and O. Sjofjan \\ Feed Animal Nutrition Department, Animal Science Faculty, Brawijaya University, Malang, East Java
}

\begin{abstract}
The research purpose was to determine nutrient content of dried of poultry waste urea molasses block (DPW-UMB). The research method was used completely randomized design with 3 treatments and 5 replicates. The treatments used for research were T1 (10\% manure of laying chicken and $25 \%$ molasses), T2 (15\% manure of laying chicken and $30 \%$ molasses), and T3 (20\% manure of laying chicken and 30\% molasses). The data analysis was the analysis of variance (anova) and continued by Duncan Multiple Range Test. The results showed that treatments has significantly difference $(\mathrm{P}<0.01)$ on dry matter, crude protein, and ash. The result of nutrients will stimulate the process of rumination and rumen contractions, which in turn will improve the fermentation process the fiber feed. It could be concluded that DPW-UMB contained sufficient levels of nutrients. It could be used as feedstuff for ruminants for supplementation with the required nutrients.
\end{abstract}

Kata kunci: Manure, DPW-UMB, Urea, Molasses

\section{Evaluasi Kandungan Nutrien Kotoran Ayam Kering Molasses Blok (Kamblok) Secara In-} Vitro

Tujuan dari penelitian ini adalah untuk mengetahui kandungan nutrisi dari kotoran ayam kering molasses blok (KAMBLOK) secara in-vitro. Penelitian ini menggunakan Rancangan Acak Lengkap (RAL) dengan 3 perlakuan dan 5 ulangan. Perlakuan yang digunakan pada penelitian ini adalah P1 (10\% kotoran ayam kering dan 25\% molasses), P2 (15\% kotoran ayam kering dan 30\% molasses), P3 (20\% kotoran ayam kering dan 30\% molasses). Data dianalisis menggunakan analisis ragam dan dilanjutkan dengan uji Duncan. Hasil menunjukan perlakuan berpengaruh sangat nyata $(P<0,01)$ terhadap bahan kering, protein kasar, dan abu. Hasil daripada ini dapat menstimulasi dan meningkatkan proses ruminansi. Kesimpulan dari penelitian ini adalah kamblok dapat digunakan sebagai pakan potensial untuk suplementasi

Keywords: Kotoran ayam kering, Kamblok, Urea, Molases

\section{INTRODUCTION}

The number of beef cattle population decreased during dry season (Andi and Wahdi, 2011). The feedlot system is not supported by the balance of quality and feed availability in dry and rainy season. The large quantity of forage was available in rainy season but limited in the dry season. Therefore, the fattening of beef cattle was restricted due to the use of rice straw for feeding. Normally, rice straw was given to beef cattle during dry season.

According to Andi and Wahdi (2011) rice straw is a by-product from grain production. Rice straw contains low protein, low fibre and nitrogen. Low nutrient content decreases rumen microbial population. Supplementation from feed which consisted of energy, mineral, vitamin, protein and non-protein-nitrogen (NPN) was essential in fattening process (Andi and Wahdi, 2011). Urea molasses block (UMB) is one type of feed supplement which contains microelements. Supplementation from the molasses block containing soluble carbohydrates provides NPN as a source of ammonia and minerals to enhance the formation of microbial protein. Bacteria produce enzymes which

\footnotetext{
*Penulis Korespondensi: Danung Nur Adli

Alamat: Jl. Veteran, Universitas Brawijaya 65145
}

E-mail: danungnuradli1994@gmail.com digest crude fibre and synthesize protein as feed source for microbial protein. Siti et al. (2012) stated that UMB consisted of rice bran, pollard, salt, lime, and mineral can be used for feed supplementation.

In addition, Andi and Wahdi (2011) stated that the nitrogen element on urea-molasses block is useful in protein synthesis. The principal of digestion in regard to forages is the rumen, where the feed is retained for substantial periods of time and subjected to extensive microbial fermentation. Waste are derivation by product of processing that still containing a lot nutrient. The utilization of urea NPN as animal feed provided in layer chicken manure (Vatta et al., 2007). Boushy and Poel (2000) stated layer manure chicken consists of pathogenic microorganism. The low content of essential amino acid and metabolic energy from the manure is suggested to its utilization less than $5 \%$ of total ration (Sinaga and Silalahi, 2012).

FAO (2010) stated the poultry industry produced 22 million tons of manure from over 18 billion population of poultry. The high poultry waste production caused negative effect to the environment from ammonia content, thus it needs to be recycled. One method to recycle is by drying the poultry waste and used it as source of nitrogen in the urea-molasses block. The research purpose was to determine nutrient content of dried of poultry waste urea molasses block (DPW-UMB). 


\section{MATERIALS AND METHODS}

The materials used for this manufacture of dried poultry waste urea-molasses block (DPW-UMB) are gloves, bucket capacity 10,000 g, plastic 500 g, UMBblock $500 \mathrm{~g}$ with shape round and love, pressing tool, and analytic scale. The principal ingredients were molasses, manure layer chicken, rice bran, limestone, cement, brick, salt, water, urea, and mineral mix. The research method was used completely randomized design with 3 treatments and 5 replicates. The treatments used for research were T1 $(10 \%$ manure of laying chicken and 25\% molasses), T2 (15\% manure of laying chicken and 30\% molasses), and T3 (20\% manure of laying chicken and $30 \%$ molasses). The poultry waste obtained from a layer farm on Magetan Regency, East Java. The poultry waste was collected from under the battery cages of laying house accommodating approximately 50,000 hens. The poultry waste collected was fresh and was not subjected any treatment on the farm. It was placed in clean plastic bags and transported to the Janggan Village, Magetan Regency. The poultry waste was drying at temperature $105^{\circ} \mathrm{C}$ for 2 hours.

The variables observed were nutrient compositions (Dry matter, crude protein, crude fibre, fat, ash, gross energy). The data analysis using analysis of variance (anova) and continued by Duncan's Multiple Range Test (Steel and Torrie, 1992).

\section{RESULTS AND DISCUSSSION}

\section{Dry Matter (DM) of Dried Poultry Waste-Urea Molasses Block (DPW-UMB)}

Based on Table 1 result from the research on the dry matter are significantly different $(\mathrm{P}<0.01)$. The content of dry matter (DM) of dried poultry waste ureamolasses block T1 is lower than T2 and T3 that table show $61.42 \%$ lower than $90.92 \%$ and $92.04 \%$. Dried poultry waste urea-molasses block packaged and sun drying for seven days. Sinaga and Silalahi (2012) stated the greater availability of dissolved carbohydrates causes increased activity of fermentation by bacteria to produce lactic acid. The fermentation activity causing loss dry matter in the dried poultry waste urea-molasses block. Decreasing dry matter is affected by respiration and fermentation respiration will cause a lot of the nutrients to break down and reduce the dry matter, while fermentation will produce lactic acid and water. The higher water produced during made of DPW-UMB, then loss of dry matter increase. Nurhayu et al. (2010) reported that molasses stimulated dry matter digestion, and even when relatively large quantities. Subsequent animal trials Wayne et al. (2003) demonstrated that the digestibility of molasses block combined with forage was noticeably reduced by molasses.

\section{Crude Protein (CP) of Dried Poultry Waste-Urea Molasses Block (DPW-UMB)}

Based on the results of the research (Table 1) administration the crude protein results are significantly different $(\mathrm{P}<0.01)$. The several factors affected are processing, formulation, and kind of material from one place. The table show the content of the DPW-UMB on crude protein (CP) T3 highest than $\mathrm{T} 1$ and $\mathrm{T} 2$ the result is $13.34 \%$ compared with $10.05 \%$ and $10.33 \%$ this is because the percentage of formulation layer manure is $20 \%$ than T1 and T2 $15 \%$ and $10 \%$. The highest are due to the level dried poultry waste given with level manure are highest than T1 and T2. Nurhayu et al. (2010) stated urea molasses block (UMB) nutrient content consist urea and molasses showed crude protein is $12.76 \%$. Crude protein $(\mathrm{CP})$ on $\mathrm{T} 3$ is $13.34 \%$ using dried poultry waste combining with molasses the statistics better than urea molasses block (UMB).

The rapidly digested nature of the sugars in molasses increases the animal's ability to utilize soluble proteins increasing microbial growth and maximizing microbial production. Comparison crude protein content on the dried layer chicken is $13.47 \%$ and dried broiler excreta is $21.59 \%$. The result was similar to Sinaga and Silalahi (2012) stated the content of protein in the dried poultry waste is $12-31 \%$ layer chicken. The negative effect that sugars and molasses appear to have on supplementation digestibility has been shown to be related to the crude protein content of the diet. Wayne et al. (2003) showed that the negative effect of glucose supplementation on the digestibility of crude fiber in hay diets of yearling cattle was completely eliminated by increasing the protein content of the diet.

\section{Crude Fiber (CF) of Dried Poultry Waste-Urea Molasses Block (DPW-UMB)}

Tabel 1. DPW-UMB nutrient content

\begin{tabular}{|c|c|c|c|}
\hline \multirow[t]{2}{*}{ Variables } & \multicolumn{3}{|c|}{ Treatments } \\
\hline & $\mathrm{T} 1$ & $\mathrm{~T} 2$ & T3 \\
\hline Dry matter (\%) & $61.42 \pm 1,76^{\mathrm{a}}$ & $90.92 \pm 0,32^{a b}$ & $92.04 \pm 0,38^{\mathrm{ab}}$ \\
\hline Crude protein $(\%)$ & $10.05 \pm 0.23^{\mathrm{a}}$ & $10.33 \pm 0,05^{\mathrm{a}}$ & $13.34 \pm 0,05^{\mathrm{ab}}$ \\
\hline Crude fiber $(\%)$ & $17.41 \pm 0.43^{\mathrm{a}}$ & $8.20 \pm 0.48^{\mathrm{a}}$ & $13.39 \pm 0.52^{\mathrm{a}}$ \\
\hline $\operatorname{Ash}(\%)$ & $27.26 \pm 0,04^{\mathrm{a}}$ & $31.69 \pm 0,19^{\mathrm{a}}$ & $37.16 \pm 0,17^{a b}$ \\
\hline Fat $(\%)$ & $3.51 \pm 0.60^{\mathrm{a}}$ & $3.95 \pm 0.38^{\mathrm{a}}$ & $3.44 \pm 0.35^{\mathrm{a}}$ \\
\hline Gross energy (kcal/kg) & $3065.8 \pm 9.85^{\mathrm{a}}$ & $2949.50 \pm 6,54^{\mathrm{a}}$ & $2631.63 \pm 6,56^{\mathrm{a}}$ \\
\hline
\end{tabular}


Tabel 2. Manure of layer and molasses nutrient content

\begin{tabular}{lcc}
\hline \multicolumn{1}{c}{ Variables } & \multicolumn{2}{c}{ Ingredients } \\
\cline { 2 - 3 } & Manure of layer & Molasses \\
\hline Dry matter (\%) & 89.94 & 67.50 \\
Crude protein (\%) & 13.47 & 3.50 \\
Crude fiber (\%) & 8.38 & 10.50 \\
Ash (\%) & 6.95 & 5.67 \\
Fat (\%) & 3.95 & 2.51 \\
Gross energy (kcal/kg) & 1657 & 2234 \\
\hline
\end{tabular}

Based on the results of the research (Table 1) administration of crude fiber did not significant effect $(\mathrm{P}>0.05)$. Crude fiber from dried poultry waste ureamolasses block on the T1 is higher than T2 and T3 from the table show $18.41 \%$ higher than 8.20 and $13.39 \%$. The $\mathrm{T} 1$ are highest due to the level of the dried poultry waste given that increasing the crude fiber. Crude fiber will stimulate the process of rumination and rumen contractions, which in turn will improve the fermentation process the fiber feed. The main result of the fermentation of fibrous carbohydrates is acetic acid. Crude fiber content of high feed can be a limiting factor for consumption. Crude fiber that is both bulky feed will stay longer in the rumen and can suppress consumption. As will be discussed later, the feeding of molasses, significantly reduces the apparent digestibility of protein. In view of the above interrelationships between levels of molasses, dietary crude protein and the digestibility of fiber, the inhibition of molasses on protein metabolism apparently is occurring in the rumen.

Nurhayu et al. (2010) stated urea molasses block (UMB) nutrient content consist urea and molasses showed crude fiber $(\mathrm{CF})$ is $6.65 \%$. Crude fiber $(\mathrm{CF})$ on $\mathrm{T} 3$ is $18.41 \%$ using dried poultry waste combining with molasses the statistics better than urea molasses block (UMB). Crude fiber is also an indicator of the low digestibility of a feed material. The digestibility of crude fiber depends on the content of crude fiber in formulations. The result match with Wayne et al. (2003) stated supplementation in the solid form effect same with the concentrate because both have a function to increase growth and number of rumen microbes. Further it increases the palatability of the ration, reduces dustiness and serves as an economical carrier for many ingredients.

\section{Ash of Dried Poultry Waste-Urea Molasses Block (DPW-UMB)}

Based on Table 1 result from the research on the ash are significantly different $(\mathrm{P}<0.01)$. Ash content from dried poultry waste urea-molasses block on the T3 is highest than $\mathrm{T} 2$ and $\mathrm{T} 1$ from the table show $37.16 \%$ higher than $31.69 \%$ and $27.26 \%$. Those condition due to the dried poultry waste formulation. The ash content from dried poultry layer waste is $6.95 \%$ combining with dried broiler waste $6.49 \%$. Ash is residues remaining after all the combustible material has been turned off. The nutritionally ash values have little importance on DPW-UMB in this component salt and limestone given the content of ash. The cement function in the DPW$\mathrm{UMB}$ is for source silica (micro-mineral) and hardener. The ash content has positive correlation with crude protein $(\mathrm{CP})$ content in dry poultry waste urea-molasses block. Nurhayu et al. (2010) stated urea molasses block (UMB) nutrient content consist urea and molasses showed ash is $14.04 \%$. Ash on T3 is $37.16 \%$ using dried poultry waste combining with molasses the statistics better than urea molasses block (UMB). Determination of total ash can be used for many purposes for this case to determine whether or not a treatment on this case made of dried poultry waste urea-molasses block. The total ash knowing type of material composed, and as a determinant of the nutritional value parameters of a feedstuff.

\section{Fats of Dried Poultry Waste-Urea Molasses Block (DPW-UMB) UMB)}

Based on the results of the research (Table 1) administration of fat did not significant effect $(\mathrm{P}>0.05)$. Lipids or fats are a heterogeneous group of organic compounds found in living microorganism. Lipid are soluble in the organic solvents like ether or chloroform. Fats are required for a long term storage of metabolic energy to supply essential fatty acids and to carry fat vitamin. Fat in the dried poultry waste urea-molasses block on the T3 is lower than T2 and T1 from the Table 1 show $3.44 \%$ lower than 3.95 and $3.51 \%$ its because condition happen from rice bran while the rice bran as gave the fats condition to the feedstuff and increase the content of the fat. Nurhayu et al. (2010) stated urea molasses block (UMB) nutrient content consist urea and molasses showed fat is $2.51 \%$. Fat on T3 is $3.44 \%$ using dried poultry waste combining with molasses the statistics better than urea molasses block (UMB). The rice bran provides some key nutrients including fat and phosphorus. Rice bran helps absorbent for the moisture contained in molasses and gives structure to the block. The fats are high digestible and reducing dustiness.

\section{Gross Energy (GE) of Dried Poultry Waste-Urea Molasses Block (DPW-UMB)}

Based on the results of the research (Table 1) administration of gross energy did not significant effect $(\mathrm{P}>0.05)$. Energy is defined as the ability or capacity to work in living organism. Energy is essential for the maintenance of life processes including cellular metabolism, growth, reproduction, and physical activity. Gross energy (GE) is the quantity of heat resulting from the complete oxidation of food, feed, or 
other substances. Gross Energy (GE) from dried poultry waste urea-molasses block on the T1 is higher than T2 and T3 from the table show $3065.82 \mathrm{cal} / \mathrm{kg}$ higher than $2949.50 \mathrm{cal} / \mathrm{kg}$ and $2631.63 \mathrm{cal} / \mathrm{kg}$. The level of gross energy highest depend on the molasses content in the feedstuff that given the sources of the energy.

Molasses is residual crop from sugarcane in the liquid form and bagasse is solid form the content of the molasses is providing energy and source of carbohydrate. The molasses taken from Rejosari sugarcane industry. The molasses is reached maximum during dry season and residues cannot utilize well in the Magetan Regency. The molasses gave $25 \%$ for $\mathrm{T} 1$ and $30 \%$ for $\mathrm{T} 2$ and $\mathrm{T} 3$. The result of $\mathrm{T} 1$ higher because during the mixing with other feedstuff molasses absorb well into dried poultry waste urea-molasses block. Molasses can be used to fulfill a portion of the energy provided by starch.

The method during made of DPW-UMB is the factor to given the result of content DPW-UMB. The result matches with Mubi et al., (2013) stated molasses and sugar are sources of energy for ruminants. Molasses can increase microbial growth in the rumen. Bata (2008) give additional information stated the main uses of molasses are as a binding agent or binder in feedstuff. The molasses act granules to improve palatability in feedstuff ration. Wayne et al. (2003) stated microbial production is high-quality by-pass protein and drastically altered rumen VFA. The result giving additional statement from Arnita et al. (2010) stated rumen microbial growth requires $\mathrm{N}$ availability as much as $1.28 \% \mathrm{~N}$ or equivalent with $8 \%$ protein.

\section{CONCLUSION}

It could be concluded that DPW-UMB contained sufficient levels of nutrients. The T3 were the best due to the nutrients. It could be used as feedstuff for ruminants for supplementation with the required nutrients.

\section{ACKNOWLEDGEMENTS}

This research has been supported by RISTEKDIKTI that qualified in the national scientific paper (PIMNAS 28) at Haluoleo University Kendari. The authors thank to Janggan Farmer group as our partner for this research.

\section{REFERENCES}

Andi, S., and A. Wahdi. 2011. Peningkatan reproduksi sapi induk Brahman cross post-partum dengan pemberian pakan supplemen multinutrient block plus medicated. Jurnal Ilmiah Aplikasi Isotop dan Radiasi 1907: 127-143.

AOAC. 1990. Association of official analytical chemists official methods of analysis, Washington, AOAC benjamin franklin station.
Arnita, A., S. Rahim, dan Noverma. 2010. Respon pemberian "blok suplemen" berbasis bahan local terhadap pertambahan bobot sapi Bali. Journal Science Peternakan Indonesia 5: 65-69.

Bata, M. 2008. Pengaruh molasses pada amonisasi jerami padi menggunakan urea terhadap kecernaan bahan kering dan bahan organik invitro. Jurnal Agripet 8: 15-20.

Boushy, A. R. Y. and V. D. Poel. 2000. Handbook of poultry feed from waste processing and use. $2^{\text {nd }}$ edition. Kluwer Academic Publishers, Netherland.

FAO. 2010. Agricultural handbook: poultry meat and eggs. 1st edn, FAO Investment Centre Division, Rome Italy.

Ghaly, A. E. and K. N. Macdonald. 2012. Drying of poultry manure for use animal feed. American Journal of Agriculture and Biology Science 7: 239-254.

Mubi, A. A., A. Kibon, I. D. Mohammed. 2013. Formulation and production of multinutient blocks for ruminants in the guinea savanna region of Nigeria. Journal of North America 4(3): 205215.

Nurhayu, A., D. Pasambe, dan M. Sariubang. 2010. Kajian pemanfaatan pakan lokal dan urea molasses blok (UMB) untuk penggemukan sapi potong di kabupaten pinrang sulawesi selatan Jurnal Teknologi Peternakan dan Veteriner 23: 194-199.

Sinaga, S., M. Silalahi. 2012. Performans produksi babi akibat tingkat pemberian ayam petelur sebagai bahan pakan alternative. JITV 7: 207-213.

Siti, S. I. G. M. A. N. W., I. M. Mudita, I. B. G. Partama, dan I. G. L. O. Cakra. 2012. Suplementasi urea molasis blok untuk meningkatkan penampilan kambing peranakan etawah yang diberi pakan hijauan gamal. Jurnal Agripet 12: 49-54.

Steel, R. G. D. and J. H. Torrie. 1992. Principles and procedures statistics. $2^{\text {nd }}$ edition. Mcgraw-Hill. Singapore.

Vatta, A. F., J. F. D. Villiers, S. A. Gumede, R. C. Krecek, N. P. Mapeyi, R. A. Pearson, M. F. Smith, M. O. Stenson, and L. J. S. Harrison. 2007. Benefit of urea-molasses block supplementation and symptomatic and tactical anthelmintic of communally grazed indigenous goats in the bulwer area, kwazulu-natal province, South Africa. Journal South Africa Veterinary Assesment 78: 81-89.

Wayne, P. T., A. E. Cullison, and R. S. Lowrey. 2003. Feeds and feeding. $6^{\text {th }}$ edition. Prentice Hall, New Jersey. 